\title{
GAGASAN KEMATIAN DAN KETUHANAN DALAM SAJAK-SAJAK ABDUL HADI WM
}

\author{
Wiranta \\ Universitas Sebelas Maret \\ e-mail: wieranta@gmail.com \\ Murtini \\ Universitas Sebelas Maret \\ e-mail: murtiniibu@gmail.com \\ Asep Yudha Wirajaya \\ Universitas Sebelas Maret \\ e-mail: asepyudha@gmail.com
}

\begin{abstract}
This research identifies deportement and concept of death from Abdul Hadi WM's poetry. Descriptive method and semiotic-structural approach were used in this research. Descriptive method used to identifies and analyze the research object to present systematic, factual, and accurate facts and concept from its population (Dirjen Dikti, 1981: 14.) Semiotic-structural approach is used to reveal the labelling system based on elements from the poetry-that is related to each other and forms one unity of organism. By analyzing Abdul Hadi WM's poem (139 poem titles), can be concluded that (1) Abdul Hadi WM poems were built from its choose of dictions, ryhimes, arrays, and typhography so that it creates death-theme sign and (2) Abdul Hadi WM is a religious poet that can describe and write his deportment about death with subtle but strong words.
\end{abstract}

Keywords: death and divinity, Abdul Hadi WM, religious poetry.

\begin{abstract}
ABSTRAK
Penelitian ini bertujuan menggali sikap dan pandangan konsep kematian dalam sajak-sajak Abdul Hadi WM. Metode yang digunakan dalam penelitian ini adalah metode deskriptif dengan pendekatan struktural semiotik. Metode deskriptif adalah cara untuk menggali objek penelitian lewat data-data, menganalisisnya dan membuat penyandraan secara sistematis, faktual dan akurat mengenai fakta-fakta dan sifat populasinya (Dirjen Dikti, 1981: 14). Pendekatan struktural semiotik bertujuan mengungkap sistem ketandaan berdasarkan unsur-unsur yang dibangun dalam sajak, yang saling berhubungan satu sama lain, sehingga membangun satu organisme. Hasil penelitian ini berdasarkan 139 judul sajak karya Abdul Hadi WM adalah (1) secara struktur sajak Abdul Hadi WM dibangun dengan utuh melalui diksi, persajakan, larik, tipografi sehingga mampu menciptakan ketandaan tentang tema kematian, (2) Abdul Hadi WM yang dikenal sebagai penyair religius mampu memaparkan sikapnya tentang kematian secara halus namun mengena.
\end{abstract}

Kata kunci: kematian dan ketuhanan, Abdul Hadi WM, sajak religius. 


\section{PENDAHULUAN}

Dalam buku Proses Kreatif: Mengapa dan Bagaimana Saya Mengarang (1984), Abdul Hadi WM menyatakan bahwa menulis puisi terutama adalah bagaimana menyelami jagad kecil ini secara kreatif. Selain itu, proses menulis puisi juga berusaha mencari getaran-getaran hidup di dalamnya dan mencoba berdialog dengan yang kekal dan menyatukannya dengan yang fenomenal (1984: 192).

Pernyataan Abdul Hadi WM (1984) tersebut tentu menarik perhatian bila dikaitkan dengan pernyataan A. Teeuw (1989). Teeuw (1989) mengatakan bahwa tema utama dari sajak-sajak Abdul Hadi WM adalah kematian, kefanaan hidup, dan kesunyian maupun waktu yang menjadi kaki tangan maut. Tema-tema itu sangat terasa melalui banyak halaman karya-karyanya (1989: 148). Demikianlah, Abdul Hadi WM telah membuktikan diri sebagai seorang penyair Indonesia modern yang memiliki obsesi yang cukup intens terhadap tema-tema religiositas, alam, dan manusia dalam sajak-sajak yang diciptakan selama ini

Dalam bibliografi puisi Indonesia modern, puisi-puisi yang mengungkapkan masalah religiositas, alam, dan manusia merupakan puisi-puisi yang banyak ditulis para penyair. Linus Suryadi AG, misalnya, justru lebih tegas lagi dengan pernyataannya bahwa tema religiositas, alam, dan manusia merupakan salah satu tema yang mendapat banyak perhatian penyair di mana pun (Linus, 1989: 138). Barangkali, pernyatan Boris Pasternak yang kemudian disitir Linus dalam buku itu memang benar (Linus, 1989: 138), yakni kesenian mempunyai dua ketekunan yang tetap dan tidak berakhir. Baginya, seni selalu bersemadi tentang maut (religiusitas) dan di samping itu seni selalu menciptakan kehidupan.

Berbeda dengan puisi-puisi Indonesia modern yang ditulis penyair lain, puisi-puisi Abdul Hadi WM memperlihatkan intensitas yang cukup mengesankan. Hal ini ditandai melalui karya-karya yang ditulis di awal kepenyairan. Sebagai contohnya adalah Laut Belum Pasang, (1970), yang disusul dengan kumpulan Potret Panjang Seorang Pengunjung Pantai Sanur (1975), Cermin, (1975), Meditasi (1976) dan Tergantung Pada Angin (1977). Kecuali sajak-sajak yang telah diterbitkan sebagai kumpulan sajak, Abdul Hadi WM juga masih menulis atau menghasilkan sajaksajak yang mengaktualisasikan tema-tema religiositas, alam dan manusia. Hal iu dipublikasikan di berbagai media massa Indonesia. Semua itu merupakan bukti betapa obsesif Abdul Hadi WM dalam menggumuli tema-tema religiusitas, alam, dan manusia.

Tema religiositas, alam, dan manusia memang bukan monopoli Abdul Hadi WM. Banyak penyair yang lain-baik penyair yang sudah mapan maupun penyair yang masih mencari tempat - juga menggarap tema religiositas, alam dan manusia. Namun, Abdul Hadi WM memperlihatkan kesetiaan yang luar biasa. Hal ini tidak dapat dikatakan sebagai kontinuitas atensi terhadap persoalan religiositas, alam, 
dan manusia. Sebagai penyair, dia hampir tidak pernah melibatkan diri secara langsung terhadap masalah-masalah sosial maupun terhadap masyarakat di sekelilingnya. Akan tetapi, "lukisan" perasaan, suasana hati, gagasan, dan pengalaman ke-aku-annya selalu menggugah pembaca untuk bersimpati dan melibatkan diri sedalam-dalamnya (Teeuw, 1989: 147).

Penelitiaan terhadap sajak-sajak Abdul Hadi WM, misalnya Sapardi Djoko Damono (1983), Dody Mardanus (1978), Ikranegara (1978), Gunoto Saparie (1979), A. Teeuw (1980), Korri Layun Rampan (1980), Umar Junus (1981), Herman Ks (1985), Subijantoro Atmosuwito (1989), cenderung melihat pemanfaatan bahasa atau proses kreatif penciptaan puisi. Sementara itu, penelitian yang khusus memusatkan pada permasalahan religiusitas, alam, dan manusia yang terungkap dalam sajak-sajak Abdul Hadi WM sampai saat ini belum pernah diteliti secara khusus. Sebagaimana yang dikatakan A. Teeuw (1989:147), hingga sekarang, sajaksajak Abdul Hadi WM tidak banyak memperoleh perhatian dari kaum kritikus. Padahal, penelitian mengenai tema-tema religiositas, alam, dan manusia dalam sajak-sajak Abdul Hadi WM dapat memberikan pemahaman terhadap proses perkembangan sikap dan pandangan Abdul Hadi WM terhadap dunia dan kehidupan di sekitarnya melalui pendekatan persoalan religiusitas, alam dan manusia.

\section{TEORI DAN METODE PENELITIAN}

Penelitian ini menggunakan adalah penelitian kualitatif dengan metode deskriptif dalam pendekatan struktural-semiotik. Metode deskriptif adalah suatu cara untuk menggali objek penelitian lewat data-data, menganalisis, dan mendekrisikan secara sistematis, faktual dan akurat mengenai fakta-fakta dan sifatsifat populasinya (Dirjen Dikti, 1981: 14).

Pendekatan struktural bertitik tolak dari suatu konsepsi bahwa karya sastra terbina oleh berbagai norma sastra. Norma-norma itu merupakan kelompok yang saling berhubungan satu sama lain, sehingga merupakan satu organisme (Udin, 1985:4). Jadi, pendekatan struktural bertujuan untuk membongkar dan memaparkan secara cermat dan detaik keterkaitan dan keterjalinan semua aspek atau usur karya sastra yang bersama-sama menghasilkan makna menyeluruh (Teeuw, 1984: 135).

Pendekatan semiotik pada dasarnya melihat karya sastra dalam sistem ketandaan. Konsep semiotik mengenalkan prinsip-prinsip yang berkaitan dengan tanda. Prinsip-prinsip itu adalah penanda dan petanda. Penanda adalah aspek formal atau bunyi pada tanda itu. Sementara itu, petanda adalah aspek kemaknaan atau konseptual dari tanda (Teeuw, 1984: 44). Hubungan antara penanda dan petanda dapat dibedakan menjadi tiga jenis tanda yaitu ikon, indeks, dan simbol. Ikon adalah tanda yang hubungan antara penanda dan petandanya bersifat persamaan bentuk 
alamiah. Indeks adalah tanda yang menunjukkan hubungan antara penanda dan petanda yang bersifat alamiah. Simbol adalah tanda yang menunjukkan hubungan antara penanda dan petanda berdasarkan konvensi masyarakat.

Karya Abdul Hadi WM dikategorikan sebagai sastra relijius atau sastra profetik. Istilah ini, menurut Kuntowijoyo, berhubungan dengan sastra yang harus menjejakkan bumi dan menjangkau langit. Artinya, sastra profetik harus dilandasi oleh kesadaran, kemanusiaan, dan kesadaran ketuhanan. Konsep atau istilah profetik sendiri diambil dari kata "prophet" (nabi).

Gagasan yang hendak disampaikan adalah meniru nabi, yakni mengurus dunia atau umat dan menghamba pada Tuhan. Sementara itu, sastra sufi atau sufistik cenderung berkonotasi hanya mengurus hubungan manusia dengan Tuhan saja. Sastra profetik harus berlandaskan pada strukturalisme transendental. Selanjutnya, Kuntowijoyo mengemukakan bahwa sastra profetik harus dibangun atas hubungan atau keterkaitan antar kesadaran, Kesadaran itu adalah kesadaran keimanan kepada Tuhan saja, dan kesadaran manusia dalam posisinya sebagai manusia (Susanto, 2015: 742).

\section{HASIL DAN PEMBAHASAN}

\section{Gagasan Ketuhanan dan Kematian dalam Sajak-Sajak Abdul Hadi WM}

Abdul Hadi WM telah menghasilkan enam buku kumpulan puisi, yakni Laut Belum Pasang, Potret Panjang Seorang Pengunjung Pantai Sanur, Cermin, Meditasi, Tergantung Pada Angin, dan Pembawa Matahari. Citra maut dan Tuhan dalam sajaksajaknya, baik verbal dan maupun tersamar, lebih intensif terekspos. Hal ini dikarenakan penyair menempatkan berbagai fenomena dengan menghubungkan berbagai dimensi transendensi kematian dan ketuhanan. Sebagai akibatnya, sajak-sajaknya tidak mau berupaya untuk menciptakan nuansa keabadian (Tuhan), misteri (kematian) dan yang terasa sebagai ketidakpastian yang sangat menggelisahkan.

Kumpulan Laut Belum Pasang, kumpulan sajak ini diterbitkan oleh penerbit LITERA, Jakarta tahun 1971. Halaman judul dibubuhi keterangan 1967 - 1971. Hal ini mungkin dimaksudkan sebagai informasi bahwa delapan belas judul sajak yang terkumpul dalam kumpulan Laut Belum Pasang ini adalah sajak-sajak yang ditulis tahun 1967 sampai 1971. Meskipun Abdul Hadi memberi judul kumpulannya dengan judul Laut Belum Pasang, delapan belas sajak-sajak yang termuat dalam kumpulan ini tidak didominasi oleh nyanyian laut. Beberapa sajak justru membicarakan hal lain selain laut.

Kumpulan sajak Laut Belum Pasang dibuka dengan sajak "Prelude". Sebagaimana yang dikatakan Harry Aveling (2003:34), sajak ini dengan indah menggambarkan kerja dua nelayan Madura ketika sedang bersiap-siap akan turun ke laut di waktu malam. Gagasan ketuhanan dan kematian disisipkan penyair melalui pertanyaan-pertanyaan 
yang termuat dalam bagian II bait kedua puisi ini.

Siapakah bertolak bersama pelaut ${ }^{2}$ itu?

angin senja dari benua. Sesekali suara sauh

Siapakah yang berseru bersama pelaut ${ }^{2}$ itu?

langit yang biru, bisik². Sesekali bayang ${ }^{2}$ negeri jauh.

Menurut Abdul Hadi WM (1996:156), sajak yang buruk biasanya berusaha meyakinkan pembacanya. Dengan demikian, hal ini memaksa untuk mendengarkan saja dengan pasif. Sajak semacam ini juga cenderung untuk mencoba menyelesaikan masalah. Menurutnya, sajak "Samar" tidak demikian halnya.

Ada yang memisahkan kita, jam dinding ini

ada yang mengisahkan kita, bumi bisik-bisik ini

ada. Tapi tak ada kucium wangi kakimu sebelum pergi

tak ada. Tapi langkah gerimis bukan sendiri.

Dalam sajak "Samar" ini, Abdul Hadi menyatakan perasaan yang samar-samar dengan cara yang sederhana, yakni menyatukannya dengan alam. Menurut Sapardi (1999: 157), dua elemen penting dari puisi lirik telah dicapai sajak ini. Sajak "Samar" dinilai Sapardi merupakan hasil pengamatan yang cermat terhadap perasaan dan alam sekitar. Menurutnya, sekarang, di mana letak gagasan ketuhanan atau kematian dalam sajak tersebut?. Hal itu terlihat dalam kesamar-samaran masalah ketuhanan dan kematian. Bagi sebagian orang, soal Tuhan dan kematian bukan soal yang cetha dan gamblang. Banyak orang merasakan sebagai soal yang samar.

Sajak "Engkau Menunggu Kemarau" tidak secara jelas mengungkapkan gagasan ketuhanan maupun kematian. Abdul Hadi lebih tertarik bermain-main dengan perasaan dan ungkapan yang digali dari fenomena alam. Perhatian kalimat pada bait kedua adalah Sebelum engkau berdiri / Pergi /Dilangit lembayung terdengar suara awan / Bahwa rawan sudah kau siapkan / Bahwa kesal sudah kau diamkan.

Rupanya, penyair suka memanfaatkan fenomena alam untuk mengaitkannya dengan gagasan ketuhanan. Sajak "Malam Laut" menunjukkan bahwa alam menjadi liang untuk memasuki tirai gagasan ketuhanan yang dimaksudkan. Hal itu terlihat dalam Dipantai engkau mencari // senja yang menyatu dengan bumi // baru ada sunyi // Dan kita tahu, ombak tidak sendiri. Hal ini memunculkan pertanyaan "Bukankah alam merupakan tangan panjang Tuhan?", "Sebab siapakah yang menjadikan segala kejadian alam?”, dan “ Siapakah yang menggerakkan alam, ombak tidak bergerak sendiri?".

Pada sajak "Angin: Mendesir Lagi", Abdul Hadi masih ingin mengangkat hal-hal yang tersembunyi. Hal ini terlihat dari Ada sepi // Berbisik di dahan-dahan pohon // Lagi tahu, gerimis turun. Ungkapan yang dipilih Abdul Hadi untuk menggambarkan fenomena ketuhanan memang sangat sublime atau sangat samar. Hal itu ditunjukkan dengan Engkau gemetar karena musim // Cemas dalam kata // Dan tahu: ada yang tiada // Bangkit di jendela. // Dan mungkin: senja. Hal ini agaknya memang harus meminjam fenomena alam 
untuk mengungkapkan berbagai hal rasa ketuhanan itu.

"Sajak Kabur" agaknya juga ingin membahas gagasan kematian dalam ungkapan yang sangat samar. Angin akan pergi dan meninggalkan kursi tua itu dapat dipadankan dengan tubuh yang ditinggalkan roh. Selian itu, hal ini muncul dalam "Dan sebuah beranda pun menunggu / terik siang, dilepaskan waktu / ruang menyelenggarakan sunyi, untukmu'. Abdul Hadi memang tidak menggambarkan peristiwa kematian dengan ungkapan yang mudah untuk dipahami. Dia selalu menggunakan simbol-simbol alam seperti sepasang cemara, langit percakapan, ruang menyelenggarakan sunyi.

Sementara itu, sajak "Ruh" mencoba menceritakan keadaan ruh. Fenomena ruh tentu terdapat dalam kehidupan pasca-kematian. Agaknya, Abdul Hadi di dalam menggambarkan fenomena ruh menggunakan referensi dari salah satu agama besar. Berikut kutipan sajak “Ruh” bait pertama

Ruh meratap dan bersedih, sayang menggetar dalam permainan api maha dahsyat ini

Ruh tiada tidur, mengembara dengan sayapnya kudus dan putih

Abdul Hadi tidak sedang membicarakan masalah kematian. Namun, dia membicarakan masalah yang berkaitan dengan kematian. Pemahaman awam fenomena ruh dapat meng-“ada" setelah melewati proses kematian. Namun, dalam sajak "Ruh", proses itu tidak harus dilewati. Dunia keabadian merupakan tempat ruh meratap dan bersedih. Ruh tidak memiliki integritas ketika menyelenggarakan kehidupan di masa lalu, menggetar dalam permainan api, maha dahsyat. Sesungguhnya, ruh tidak memiliki pancaindra lagi, ruh tiada tidur, mengembara dengan sayapnya, yang kudus dan putih.

Selanjutnya, sajak “Gnoti Seauton” mencoba mengangkat gambaran ketuhanan dengan menggunakan fenomena ruh. Hal ini terlihat dalam penggalan sajak atau bait "Manusia bebas, ruhnya bagai / firman Tuhan, embun dalam cuaca putih/mencucinya / Manusia bebas, ruhnya berjalan / ketempat ${ }^{2}$ jauh dan menemui para nabi dan orang suci". Rupanya, dalam sajak "Gnoti Seauton" ini, Abdul Hadi ingin menyingkap yang tersembunyi. Ruh-ruh berkelana dan berkehendak menggapai safaat para nabi dan orang suci. Manusia bebas tidak dalam keadaan terbelenggu oleh nafsunya - mampu menemukan bayang-bayang Tuhan. Oleh karena itu, Di gerbang kuil besar: Ruh terbang dan tidak kembali menemukan firdaus tempat dia bermukim untuk selama-lamanya.

Selanjutnya, sajak "Hotel" mencoba menangkap tema ketuhanan dari aspek kesadaran hubungan makhluk dan khaliq. Hubungan antara makhluk dan khaliq dalam sajak tersebut dinyatakan Abdul Hadi dengan ungkapan Dan kita hanya bercakap ${ }^{2}$ sebentar, tentang istirahat pendek ini / Kemudian berhenti, pasrah dan diam² mendo'a / Ketika jam dinding bergerak melewati sebuah angka. Sajak ini jelas hendak mengemukakan kesadaran bahwa makhluk sangat lemah dan khaliq adalah sangat kuat. Makhluk harus mendo'a dan 
memohon segala sesuatunya.

Sementara itu, sajak "Mesjid" menggambarkan proses pencarian kepercayaan agung yang sering dimaknai dengan Tuhan. Abdul Hadi seacra langsung memilih simbol-simbol yang genah dan pasti, Masjid. Seluruh ungkapan sajak "Masjid" dapat dikatakan membawakan nuansa ketuhanan.

Sajak tersebut sangat kental dengan ungkapan-ungkapan yang membawa imajinasi ke situasi proses kekhusyukan seseorang ketika sedang berhadapan dengan Allah Swt. Sekalipun bagi seseorang Allah ada dan tiada, seseorang harus tetap memanjatkan doa untuk menyatakan dirinya adalah makhluk ciptaan Allah Swt. Hal ini tidak dikotori oleh pikiran-pikiran atau perasaan-perasaan yang tidak pernah memahami eksistensi-Nya yang memang gaib.

Sajak "Memandang" memuat tema kematian yang dikemas dengan penuh simbol-simbol yang sangat rumit untuk dipahami. Beberapa ungkapan mungkin dapat menjadi petunjuk untuh mendalami masalah kematian yang diangkat Abdul Hadi. Misalnya, kalimat-kalimat pada bait 4 dan bait lima, dan aku dan kau berjalan mencari / sisa gerimis dari taman itu / sebagai arwah terkutuk yang beterbangan / di atas teluk bandar medan peperangan // dimanakah tubuhmu dan tubuhku / dibaringkan? Jika gugur dan mati / dimanakah sukmaku dan sukmamu / dibaringkan? Jika tak bisa istirah sampai nanti menunjukkan hal tersebut. Penggelan dua bait dari sajak "Memandang" tersebut memberi gambaran masalah kematian yang hendak dikemukakan Abdul Hadi. Menurutnya, kematian tetap sebuah persoalan yang samar-samar sehingga yang muncul dalam pikiran-pikiran penyair juga berbagai pertanyaan yang tidak dapat dijelaskan.

Kumpulan Potret Panjang Seorang Pengunjung Pantai Sanur, sajak "Pertemuan" dalam kumpulan menggambarkan pertemuan antara sang makhluk dan sang khaliq. Pertemuan tersebut tidak harus dalam keadaan berdoa atau beribadah rituali, misal sholat lima waktu, tetapi dalam berbagai intensitas ibadah-ibadah yang lain sebagimana yang diungkapkan Abdul Hadi dalam sajaknya. Hal itu terlihat dalam bait yang mengemukan Siapakah di mesjid jauh itu? / Sujud dan mendo'a? Membacakan surat Yasin yang panjang. Waktu / angin merendah / Ia hilang di puncak. Dalam kekhusyukan tersebut, seseorang - biasanya seorang sufi- merasa hilang kesadaran karena hanyut dalam peribadatan tersebut.

Sajak "Gapura" tidak secara jelas mengungkapkan gagasan kematian. Namun, pembaca mungkin bisa memberi tafsir sendiri atas sajak ini. Konsep "gapura" mungkin dapat menjadi simbol yang menggambarkan sebuah lubang semacam pintu masuk ke alam kematian. Abdul Hadi membuat ungkapan yang digali dari fenomena alam yang sangat liar, mengapa kereta / menempuh padang kerjaan alam?/ mengapa kuda-kuda / meringkik gempita di cakrawala?. Ungkapan pada bait kelima adalah ya hatiku: sipingang dan gembira, brontak / di depan gapura / dan undur kembali / mengapa kereta / menempuh padang kerajaan silam? / kuda-kuda meringkik / menggeledah kelam. 
Sajak yang diberi judul “Sajak Putih" merupakan penggarapan tema kematian yang diungkapkan dengan pilihan kata (diksi), yang sangat mengesankan. Abdul Hadi memanfaatkan konsep masa silam dalam menggambarkan "seseorang" telah melewati fase kematian. Perasaan terasing karena sudah tidak memiliki media yang sama dalam mengekspresikan kesadaran hidup. Persepsi manusia terhadap yang sudah mati berbeda-beda. Abdul Hadi menggunakan kata menjadi sekedar kenangan, lembaran asing pada buku harian, bungabunga berguguran, pohon-pohon kering, kaca jendela kusam, seperti senja bakal tenggelam, seakan cairan lilin yang mengenntal jadi malam, masa indah (hidup dan kehidupan) hanyalah onggokan puntung rokok. Hal ini menunjukkkan gambaran kematian yang luar biasa, yang diangkat Abdul Hadi dalam sajak ini.

Sajak "Lagu Senja" mencoba menggambarkan gagasan ketuhanan yang terburai dari tangkapan alam. Abdul Hadi justru menemukan berbagai pertanyaan di hamparan kemahakuasaan Tuhan yang terejawantahkan dalam berbagai fenomena alam. Abdul Hadi merasakan kebesaran tersebut berhadapan dengan keindahan alam. Senja musim hujan yang beku / Akan mengalir ke manakah angin / Selagi semua gapura malam tertutup / Bulan hanyut seperti perahu-perahu nelayan di laut malam? Selanjutnya sajak yang diberi judul "Sajak dan Lapar Kedengaran" mencoba mengangkat tema sosial namun dipadukan dengan nuansa ketuhanan. Ungkapan seperti dan lapar kedengaran: / Angin larut / Udara celaka / Tuhan mengelakkan diri / Hanya laparku menggema, menunjukkan bahwa Abdul Hadi memiliki kesadaran akan hubungan bumi dan langit.

Sajak yang berjudul "Penjelmaan-Penjelmaan" sesungguhnya membahas gagasan kematian yang teraktualisasi dalam berbagai fenomena. Dalam sajak tersebut, kematian digambarakan Abdul Hadi dengan berbagai gejala. Ungkapan-ungkapan seperti, Elangelang laut yang sedih / mengikuti ombak ke pantai / di mana terdampar ratusan mayat / dan segera sang elang / menjelma nisan-nisan berlumut / yang terbang kembali ke atas pelabuhanpelabuhan adalah contohnya. Sajak yang ditulis Abdul Hadi ini mengisahkan peristiwa pembajakan yang terjadi di sebuah kapal.

Sajak "Elegi I" mengangkat gagasan ketuhanan dan kematian secara bersamasama. Sajak "Elegi I" ini diawali dengan baris Di sorga: ada juga derita. Kalimat pertama sajak ini sungguh luar biasa karena berkehendak menghancurkan mitos yang selama ini dipahami oleh para pemeluk agama samawi. Mitos tersebut adalah bahwa di surga sudah tidak ada lagi penderitaan. Surga hanya ada kenikmatan. Kalau masih ada penderitaan, hal itu bukan surga lagi.

Sajak "Pelabuhan Ini, Aku Tak Tahu”, menggambarkan kesadaran Abdul Hadi atas misteri kehidupan yang ditunjukkan dalam dinamika manusia pelabuhan. Sajak terakhir dari kumpulan Potret Panjang Seorang Pengunjung Pantai Sanur adalah "Suatu Hari, Katamu, Matahari”. Sajak ini hampir senada dengan sajak “Pelabuhan Ini, Aku Tak Tahu". Sajak ini menggambarkan kesadaran penyair atas misteri kehidupan yang ditunjukkan dalam dinamika manusia pelabuhan. Hal yang membedakan berada pada 
sajak "Suatu Hari, Katamu, Matahari”. Abdul Hadi melanjutkan pada pertanyaan yang timbul dari peristiwa manusia-manusia yang berada di pelabuhan.

Kumpulan sajak Meditasi, sajak "La Condition Humaine" secara samar menceritakan religiusitas seseorang yang dibentuk oleh situasi dan kondisi. Dengan menggunakan simbol-simbol alam, Abdul Hadi membawa pembaca ke sebuah makna hubungan manusia dengan aspek ketuhanan. Hal ini muncul dalam Aku hanya sebatang pohon mangga / - tidak berbuah tidak berdaun - / Ayahku berkata, "Tanah tempat kau tumbuh / memang tak subur nak," sambil makan / buah-buahan dari pohon kakekku dengan lahapnya.

Sajak "Bayang-Bayang" menggambarkan hasrat manusia yang selalu mencari hal yang hakiki. Sinar yang bercahaya adalah sinar hati dan cahaya akal yang menunjukkan iman. Ainul basirah adalah cahaya ilmu (nurul ilm) dan haqul basirah (menyaksikan adanya Allah dengan mata hati yang terang benderang) itu adalah cahaya akal. Diri mereka menjadi saksi atas akal mereka dan juga menyaksikan adanya Allah dengan mata akal dan mata hati. Tuhan sangat dekat dengan mereka yang bermakrifat kepada-Nya. Hal ini muncul dalm bait Mungkin kau tak harus kabur, sela / bayangbayangmu / yang menjauh dan menghindar / dari terang lampu.

Sajak "Maut dan Waktu" menggambarkan diskusi antara maut dan waktu. Masing-masing merasa lebih unggul daripada yang lain. Maut merasa dialah yang memperdaya waktu sehingga melupakan rumah (jasmani) yang seharusnya diajak menemukan suara merdu para nabi yang membawa kebenaran. Namun, di pihak lain, waktu justru yang memperdaya maut sehingga dia harus melakukan tindakan yang seharusnya tidak perlu dilakukan.

Sajak "Meditasi" menggambarkan keadaan ketauhidan manusia yang terus menerus berusaha menemukan sosok keabadian, Tuhan Semesta Alam. Berbagai agama diturunkan ke alam semesta. Namun, hal itu tidak membuat manusia merasa menemukan kesempurnaan, Akupun sudah letih naik turun candi, ke luar masuk gereja dan mesjid. Kekisruhan perasaan manusia tidak saja dialami manusia dari satu tempat. Semua manusia yang berada di belahan dunia mana saja menglami dan tetap kisruh. Ungkapan Abdul Hadi adalah Tuhan makin sempit rasa kebangsaannya, / Musa! Musa! Akulah tuhan orang Israel!" teriaknya. / Di mesjid, di rumah sucinya yang lain ia berkata pula: / "Akulah hadiah seluruh dunia, tapi sinarku memancar di Arab. Hal ini menimbulkan pertanyaan "Apakah Tuhan hanya untuk bangsa Arab dan bangsa-bangsa di Timur Tengah. Apa kekurangan orang Jawa?/ Kunyanyikan Bach dalam tembang kinanti dan kupulas Buddha jadi / seorang dukun Madura". Meskipun berbagai petunjuk sudah diberikan manusia tetap tidak dapat menerima, hal ini tetap memunculkan pertanyaan, Tuhan siapakah namaMu yang sebenarnya? Dari manakah asalMu? / Apakah kebangsaanMu? Dan apa pula agamaMu?

Sajak "Makam" menunjukkan pemahaman dan pengetahuan Abdul Hadi berhubungan dengan peristiwa kematian dan konsep kematian yang terdapat dalam 
agama Islam. Berkenaan dengan peristiwa kematian, penyair menulis "Sebuah makam baru ditutupkan / dan kesenyapan dinding yang gemetar / serta jalan terhantar / di sekitar. / Hati pedih si mati / menggeliat dari gelap ke gelap". Peristiwa kematian tentu saja menimbulkan kesedihan bagi orang-orang yang ditinggalkan. Berbagai kenangan, perasaan, dan imajinasi sering muncul dan menggoda mereka yang ditinggalkan. Namun, perasaan sedih tentu saja bukan hal yang mustahil karena hubungan batin antara yang meninggal dengan yang ditinggalkan. Kepercayaan bahwa si mati berada di alam kubur masih menghadapi berbagai kemungkinan kemungkinan diturunkan dari kepercayaan seseorang yang diperoleh dari agama yang dianut. Dalam sajak "Makam" misalnya, Abdul Hadi membawa pembaca pada kepercayaan yang terdapat agama Islam, Ketika bara sekali lagi mendera / jiwanya. Tapi antara dukanya dan dunia / tak ada lagi baras. Hal ini menegaskan bahwa si jenazah dalam hidupnya tidak mengalami kehidupan dengan nyaman dan tidak menjalani kehidupannya sesuai kaidah-kaidah keagamaan. Sebagai akibatnya, hidup dan mati nyaris tidak ada bedanya.

Sajak "Tuhan, Kita Begitu Dekat" terasa sangat religius karena semuanya mengandung ungkapan perasaan ketuhanan. Sajak ini menggambarkan betapa akrab perasaan penyair dengan Tuhan Semesta Alam. Kehidupan dan karya-karya para sufi yang sering menunjukkan fenomena kecintaan seseorang kepada Tuhan. Seperti yang dikatakan Dr. Javad Nurbakhs, sufisme mengajarkan bahwa realitas tidak dapat diketahui oleh metode-metode logis dan rasional. Tuhan harus didekati melalui cinta dan hanya melalui keagungan dan rahmat Ilahi sehingga intimasi bersama-Nya bisa tercapai. Perspektif kaum sufi dapat dikatakan bahwa sepanjang engkau masih dirimu sendiri, engkau tidak dapat mengenal Tuhan, selubung terbesar antara engkau dengan realitas adalah dirimu. Hal ini dapat dikatakan bahwa api cinta Ilahi yang dapat membakar egosentrisitas.

Sajak "Kemudian Kaususun" menggambarkan keterpisahaan manusia dengan Yang Maha Cahaya yang Suci. Pada mulanya, manusia adalah roh yang berada dunia "Kesucian". Kemudian, dia terlempar, dunia yang lahir, di alam semesta. Hal ini dapat diparafrasekan bahwa beranak-pinak, Anak-anak, yang melompat dan lari yang terciptakan dari tulang-tulang, tidak semuanya dapat dilihat dan didengar hati, semuanya lidah dan jiwa dibentuk cuaca dan kata-kata. Manusia menurut Abdul Hadi sesungguhhnya akan kembali kepada Yang Maha Cahaya dan Suci. Suatu saat tanpa, dia dikehendaki sekalipun akan memisahkan tanganku tiba-tiba dari dunia.

Sajak "Tangan" yang diperuntukan bagi sesama penyair, Sutardji Calzoum Bachri, agaknya dimaksudkan sebagai sebuah pujian. Jadi, sajak ini tidak membicarakan tema maut maupun ketuhanan. Hal itu juga muncal pada sajak "Kubawa Kau Ke Pagi Hariku”, “Ombak Itulah", "Padaku Kaukirim", dan "Perahu”. Sajak itu juga tidak membahas persoalan yang berkaitan dengan masalah kematian atau ketuhanan. 
Sajak "In Memoriam Amir Hamzah" menggambarkan kematian penyair besar Amir Hamzah yang mengenaskan. Mungkin, kematian bagi Amir Hamzah adalah kesalahan. Beberapa baris sajak Abdul Hadi mengesankan demikian, Tanganmu: Mulut yang mengucapkan kebenaran ombak / Tapi pendayung-pendayung datang terlambat // Kita jenguk ke air. Obor itu menyalakan malam. / Angin itu angin kita. Tapi tak menghembus sampai senja / lain tiba. Penyair melihat bahwa kematian sangat perkasa menghabisi. Hal ini ini memang sudah takdir atau karena kebodohan manusia yang semena-mena merenggut nyawa orang lain.

Sajak "Doa I" dimaksudkan sebagai sebuah pengakuan atas kelemahan seorang manusia di hadapan Yang Maha Kuasa. Hal terlihat dalam bait "Kalau ada tangan yang mengeluarkan kenyang dari perit nasi / hingga enyah lapar ini, Kaulah tangan itu // Kalau ada kenyang yang meliputi nasi hingga terherak tangan / ini membukanya, Kaulah kenyang itu // Kalau ada nasi yang menghidupkan kembali jiwa lapar hingga / bangkit kekuatan tangan ini, Kaulah nasi itu". Dengan demikian, sajak ini meski memilih judul "Doa", tetapi isinya adalah sebuah kesaksian atas kekuatan Tuhan Semesta Alam.

Sajak "Doa II" nampaknya menggambarkan rasa syukur para nelayan yang selalu melaut. Samudera yang mengendalikan nelayan sangat tergantung mengalirnya angin, Tuhan, kami yang berumah di udara dan air, / bahagia beroleh angin dapat lagi mengalir. Hal ini menunjukkan bahwa yang menguasai alam semesta adalah Tuhan sehingga rasa syukur tersebut selalu dipanjatkan kepada-Nya yang selalu menggerakkan angin untuk kehidupan para pengendali perahu, para nelayan.

Sajak "Dialah Gelombang Tahun-Tahunku”, "Jalan”, dan "Bahkan” tidak secara jelas membicarakan tema kematian atau ketuhanan. Sajak "Di Bumi Tak Ada Bisik-Bisik Lagi" justru mengangkat padang kematian yang disaksikan penyair di perbatasan LaosThailand. Karena dalam situasi perang, kematian seolah ada di mana-mana. Abdul Hadi mengungkapkannya dengan kalimat mati itu hanya bersama pasir dan tulang belulang / dari selnya jiwamu ingin kembali bertualang. Sajak "Dekaplah" dan "Kaulah"agaknya tidak sedang membawakan tema kematian dan ketuhanan. Keduanya membicarakan masalahmasalah personal.

Kumpulan sajak Pembawa Matahari, Abdul Hadi W.M. adalah penyair laut. Dia menulis sejumlah sajak tentang laut. Bahkan, pilihan sajak terbaiknya dikumpulkan dalam antologi berjudul Anak laut, Anak Angin (1983). Sajak-sajaknya memang banyak dipenuhi oleh idiom-idiom laut, yang bagi penyair begitu misterius. Sedemikian misteriusnya, laut seakan tidak pernah habis mengandung misteri kehidupan. Misteri laut seolah adalah misteri kehidupan. Abdul Hadi tampak begitu intens berdialog dengan laut, menyelami misterinya, menangkap kandungan batinnya, dan memberikan nuansa dan makna pada kekayaan yang ditemukannya di sepanjang perjalanan menelusuri semesta laut. 
Sajak "Al Hallaj" sangat emosional menggambarkan kematian. Hal ini dianalogkan dengan fenomena darah, Percik darah, darah secawan / meluas jadi kolam, jadi lautan / Darah mekar, jadi kembang di taman / Tunas menyembul, sungai-sungai mengalir. Sajak ini menggambarkan tragedi yang dialami seorang sufi besar Husayn Ibn Mansur yang juga dikenal dengan "al Hallaj" (w. 309/922). Karena dituduh melakukan bid'ah, di dalam persidangan, dia dijatuhi hukuman mati dan digantung.

Sajak "Kertanagara" mengambil tema kematian. Sajak "Kertanagara” menyertakan anak judul "Fragmen Hari Akhir". Sajak ini melukiskan kerajaan Singosari menjelang tumpas oleh pemberontakan. Sajak ini mencoba memotret nuansa seorang raja di tengah ujung-ujung tombak dan segala macam persenjataan yang ditancapkan oleh para prajuritnya. Semua menjelma dalam kematian. Kalimat Darimana datang bibit ketiadaan ini? / Sekonyong-konyong menyembul tunasnya, menyiratkan nuangsa kematian. Pertanyaannya adalah bahwa kalau maut sudah berada di depan, adakah kekuatan yang mampu menolong?, Tuhan, kepada apakah sekarang / Aku harus berpegang? Hal itu adalah pertanyaan putus asa. Pada waktu masih berkuasa, hal itu seolah tidak ada kematian, Hidup serasa kekal selama ini / Aku merasa takkan pernah mati / Aku mencekeram di mana-mana/ Menanamkan cakar.

\section{Sikap dan Pandangan Abdul Hadi WM terhadap Masalah Ketuhanan dan Kematian}

Berdasarkan pembahasan sajaknya, sikap dan pandangan Abdul Hadi W.M. terhadap masalah kematian dan ketuhanan memperlihatkan berbagai wawasan dan pendapat sebagai seorang manusia Jawa-Madura. Sikap dan pandangan itu memiliki daya tampung dari berbagai fenomena kebudayaan yang pernah dialami dalam proses pertumbuhansebagai penyair dan intelektual. Berikut adalah kesimpulan dari pembacaan atas sajak-sajaknya.

Bagi Abdul Hadi W.M., eksistensi Tuhan dapat dilacak melalui kepastian takdir. Manusia ditakdirkan menjumpai kematian. Ada kekuasan yang sangat adi kuat dalam peta jalan hidup manusia. Manusia hanya dapat berupaya, tetapi segala sesuatu tetap sudah ada yang memainkannya. Di dalam dialog dengan takdir, bayang-bayang Tuhan menampakkan kekuasaan. Bahkan, Abdul Hadi W.M. menyaksikan dalam berbagai hal pengejawantahan Tuhan yang penuh teka-teki (Al-Maruf, 2012:115-116).

Manusia memang tidak selalu merasa jauh dengan Tuhan. Di dalam perasaan jauh dengan Tuhan, manusia mencoba mendekat dengan mengadakan "Doa". Perilaku berdoa ternyata sebagai solusi penyair untuk menunjukkan kedekatannya dengan Tuhan di dalam melihat berbagai gejala alam. Gejala itu merupakan isarat kehadiran Tuhan. Doa juga dapat dianggap sebagai pertemuan yang intensif. Meskipun demikian, kadangkadang, orang di dalam berdoa juga mudah terjebak di berbagai hal.

Menurut pandangan Abdul Hadi W.M., kemerdekaan dan kebebasan manusia tidak diciptakan Tuhan, tetapi oleh manusia. Justru di dalam kebebasan, manusia harus 
menciptakan kesadaran bahwa pada galibnya dia adalah seorang manusia yang lemah, yang hidup, dan ada karena kehendak Tuhan. Kalau manusia tidak sanggup melihat bahwa di dalam kebebasan justru terbayang ketidakbebasan, dia harus selalu waspada jangan sampai terjatuh ke dalam situasi yang akan menyeretnya ke tingkat yang paling nista.

Beberapa sajak Abdul Hadi W.M. memperlihatkan ambivalensi yang lebih dari sekedar puisi keagamaan. Ajaran agama Islam memang nampak dalam beberapa sajaknya. Namun, hal itu agak berbeda dengan sajak-sajak yang ditulis oleh para penyair yang berasal dari agama Islam. Abdul Hadi W.M. tidak ingin menampakkan ikatan dengan tradisi keagamaan apa pun. Puisinya merupakan ibadat yang personal, suatu perhubungan dengan Tuhan yang kadang-kadang tampil secara tidak terduga. Tuhan bukanlah masalah yang sudah selesai bagi Abdul Hadi W.M.,. Dia merupakan suatu proses penemuan. Di dalam proses pencarian, Abdul Hadi W.M. kadang-kadang menemukan misteri yang sering menimbulkan berbagai pertanyaan yang tidak dapat dijawab dengan mudah.

Abdul Hadi W.M. mencoba membuat kesimpulan mengenai kepercayaan sebagian orang tentang keberadaan Tuhan di dalam menjemput kematian. Akan tetapi, hal itu memang tidak kurang rumitnya bila berhadapan dengan sesuatu yang menggelisahkan hidup sepanjang waktunya. Dia menyebut sebuah nama, tetapi nama tersebut tetap sesuatu yang tisak dikenalnya. Pengalaman masa kecil kadang-kadang mengingatkan Abdul Hadi W.M. pada berbagai hal yang dapat dianggap tanda, yang sering secara tidak sadar muncul di berbagai tempat di hadapannya. Namun, berbagai tanda itu menjadi cair dan profan kalau seseorang menganggap sebagai sesuatu yang tidak kudus. Cahaya, bintang, dan angin dirasakan sebagai sebuah kesucian sebab dengan keberadaan berbagai unsur alam yang dirasakannya. Hal itu menampilkan keabadian, kekuatan, dan transendensi. Semua dirasakan sebagai sebuah isyarat untuk selalu merebut diri-Nya.

Penghayatan mengenai waktu juga membersitkan sesuatu yang profan dan kudus. Semua waktu itu heterogen, tidak sama kepadatan, dan nilainya. Baginya, waktu dibedakan menjadi dua jenis, yaitu waktu profan dan waktu kudus. Waktu profan adalah waktu biasa dalam peristiwa kehidupan sehari-hari. Waktu kudus adalah waktu yang diciptakan dan dikuduskan Tuhan, timbul pada zaman bahari. Waktu kudus merupakan waktu yang diceritakan dalam mitos-mitos, bukan bagian dari waktu historis, tetapi merupakan asal. Akan tetapi, kadang-kadang manusia tidak menyadari betapa kelirunya selama ini. Waktu dianggap homogen. Abdul Hadi W.M. mengajak untuk mengakui dan menyadari eksistensi Yang Abadi dalam fenomena waktu.

Selanjutnya, Abdul Hadi W.M. juga mengalami konflik batin seperti konflik yang terjadi antara kekuatan gelap (ateis) dan kekuatan terang (teis). Dia selalu ingin menjadi yang pertama dan keluar sebagai pemenang di dalam memerangi kekuatan ateis. 
Manusia pada galibnya selalu ingin menjadi "yang baik" sebagai kodrat bahwa yang baik, yang Kudus adalah dari Tuhan. Kekuatan gelap pasti berasal dari ajakan nonTuhan yang dikiaskan sebagai dimensi kegelapan.

Ruang transendensi merupakan suatu inklinasi spesifik yang inheren pada aspek otonom dari kesadaran manusia. Budi manusia memiliki satu sikap khas yang terus menerus mendorong (insurgent attitude) manusia dan secara konstan mengarahkannya kepada realitas lain yang sifatnya transenden. Budi manusia, lambang cinta sejati, sumber denyut kehiduapan, tidak pernah berhenti bertanya tentang sumber dan asalnya. Manusia, pada dasarnya, berusaha untuk menemukan arti terakhir tentang eksistensinya. Dalam sajak ini, hal ini dikiaskan dengan sebuah muara, termasuk tindakan dan relasinya dengan hal-hal yang ada di sekitarnya.

Apresiasi religiusitas yang dialami seorang yang hidup bermasyarakat menyebabkan hidup benar-benar dijalankan. Baginya, Tuhan dirasakan amat bermurah hati terhadap manusia dengan mengkaruniai berbagai rahmat tanpa pamrih apa-apa.

Oleh karena itu, manusia harus memperlihatkan usahanya untuk mencapai hakikat yang paling tinggi, yakni pencapaian dimensi ketuhanan. Meskipun dengan pada galibnya, manusia dikungkung oleh berbagai hal yang dirasakan sebagai keterbatasan. Akan tetapi, hal itu justru berada dalam usaha untuk mengatasi keterbatasan. Dia mencoba menemukan sesuatu di balik teka-teki ketakterbatasannya. Hal ini susah menguraikan teka-teki atau absurditas eksistensi. Pertanyaan yang muncul pada dirinya adalah ini siapa, darimana, atau kembali ke manakah setelah kehidupan ini berakhir. Hal itu membawa manusia ke dalam diskusi panjang dan melelahkan.

Bagi Abdul Hadi W.M., fenomena Tuhan yang sejati adalah rahasia dan menggejala di dalam berbagai realitas, baik terbayang maupun tersamar. Fenomena Tuhan selalu menjadi teka-teki. Hal yang paling menakjubkan justru berada pada yang misterius. Kadang-kadang, istilah Sang Cahaya justru 'melahirkan' kegelapan lain dalam proses penemuan Tuhan.

Manusia kadang mengalami kegamangan bila berhadapan dengan misteri Tuhan. Setiap fenomena kehidupan mampu menghadirkan-Nya. Akan tetapi, dimensi Tuhan, bagi Abdul Hadi W.M., tetap sebuah misteri yang berlapis-lapis. Ada yang mengatakan bahwa Tuhan dan kematian merupakan dua masalah yang berbeda. Baginya, peristiwa seperti kelahiran, kematian, dan Tuhan merupakan garis makna yang tidak pernah putus. Unsur kesakitan dalam persalinan pada wanita yang sedang mengandung seringkali dikorelasikan dengan peristiwa kematian.

Pandangan Abdul Hadi W.M. mengenai kematian dapat dijelaskan sebagai berikut. Kematian adalah sebuah cekaman rasa sepi dan duka. Kedua fenomena itu diangap sebagi dua titik dalam posisi garis kematian yang terhubung. Oleh karena itu, sepi dan duka dapat dipandang sebagai 'ruh' kematian. Kematian yang melemparkan manusia kembali ke lorong alam baka. Bagi Abdul Hadi W.M., kedatangan peristiwa 
agung yang disebut kematian dapat dipandang sebagai tenggelamnya waktu kini ke dalam jurang yang telah silam dan mengkristal menjadi kenangan. Alam dunia maya yang sempat dinikmati dan diamati akan ditinggalkan. Kehidupan menurut ukuran fisik seperti waktu yang berlalu begitu cepat tanpa terasa. Maut dirasakannya datang demikian cepat. Hal ini membuat siapa pun terpesona.

Abdul Hadi WM mendengar bisik kematian yang lahir dari suasana sunyi. Hal ini menukik ke dalam relung kalbu melalui gejala alam. Dalam peristiwa hujan yang riwis dan suasana hati yang sesak, bisik kematian tersebut muncul. Bayang Tuhan dan kematian disaksikan dalam berbagai hal. Banyak orang melihat kehidupan dunia ini sebagai sebuah tempat penghentian sementara. Hal ini akan membawa ke sebuah tempat tujuan lain. Tempat atai tujuan yang tidak perlu bernama.

Kematian terkadang dilihat sebagai salah satu pintu untuk mengetahui eksistensi manusia. Peristiwa tersebut memberikan kesadaran terhadap keberadaannya. Manusia harus selalu mengingat bahwa segala sesuatunya harus diperhitungkan. Sebab, isarat muncul secara mendadak. Kalau tidak, orang sering terjatuh ke dalam situasi terlambat setelah segala sesuatunya sudah tidak dapat dibereskan lagi.

Perasaan takut yang amat luar biasa itu menjadi masalah yang ingin dikemukakan Abdul Hadi WM. Hal ini bagaikan berada di alam mimpi. Orang tidak dapat mengetahui kehadiran atau ketakhadirannya. Namun, hal itu membuat siapa pun gugup dan pasti menemui kematian. Hidup kadang-kadang memang penuh dengan acara dan kesibukan. Orang mudah terlupa terhadap hal-hal yang berbau kematian. Agaknya, Abdul Hadi W.M mencoba mengingatkan kejadian itu.

Pada kesempatan lain, manusia sering juga berbantahan dengan keinginannya. Di satu sisi, dia masih ingin melanjutkan perjalanan hidup yang penuh dengan berbagai petualangan. Namun, seseorang hendaknya menyadari keterbatasannya. Abdul Hadi WM menampilkan masalah kematian dalam kemasan isyarat yang indah. Setidaknya ada tiga hal yang membawa imajinasi pembaca ke dimensi kematian yaitu (1) isyarat

sekawanan gagak terbang berputar-putar, (2) isyarat bau bangkai, dan (3) isyarat perasaan takut. Burung gagak selalu dipergunakan untuk mitos-mitos yang terkait dengan peristiwa kematian.

Gambaran kematian terasa demikian bengis, kejam, dan dahsyat. Biasanya, jenazah orang mati akan diupakara secara baik-baik dan dikebumikan baik-baik. Hal ini bertujuan agar si mati yang sudah tidak bernyawa itu mendapatkan ketenangan yang sudah menjadi haknya. Akan tetapi, ada jenasah diperlakukan dengan sewenangwenang. Dia dibuang ke semak-semak yang tidak terurus dan tidak pernah ambil peduli.

\section{Makna Tema Kematian dan Ketuhanan pada Sajak-Sajak Abdul Hadi WM}

Abdul Hadi W.M. adalah salah seorang penyair Indonesia modern yang memiliki kepekaan khusus dalam mengekspresikan tema-tema kematian dan ketuhanan dalam 
sajak-sajaknya. Dengan sajak-sajaknya, dia menunjukkan bahwa tema-tema ketuhanan dan kematian menjadi persoalan yang senantiasa menggejala dalam berbagai aktivitas kehidupan. Mungkin, hal inilah yang menyebabkan Abdul Hadi W.M. termasuk salah seorang penyair religius Indonesia modern. Tema-tema seperti ini juga diangkat oleh penyair yang lain (Efsa, 2015) Makna tema ketuhanan dan kematian pada sajak-sajaknya dapat dijelaskan sebagai berikut.

Manusia dalam melihat takdir ada yang menggunakan kerangka berpikir fatalisme. Artinya, dia hanya menyerah, pasrah, sumarah tanpa memanfaatkan kemampuan yang telah dibawanya. Manusia yang demikian sudah barang tentu keliru melihat aktualisasi Tuhan dalam fenomena takdir. Manusia harus menggali lebih cermat dalam menemukan Tuhan di balik tirai takdir.

Manusia pada galibnya makhluk yang tidak peduli terhadap kasih sayang Tuhan. Ketersediaan udara segar yang dalam bahasa takdir - sudah diberkahkan kepada umat manusia oleh Tuhan tidak pernah menyentuh nurani. Manusia lupa terhadap besarnya kasih Tuhan terhadap umatnya.

Di dalam pengakuan dan ketakberdayaan, manusia berhadapan pada kekuasaan Tuhan Yang Besar. Oleh sebab itu, manusia sudah selayaknya menunjukkan dengan berdoa. Doa merupakan salah satu cara untuk menunjukkan kebesaran Tuhan dengan meminta berbagai hal untuk memenuhinya. Bukankah, Tuhan tempat meminta yang sebaik-baiknya. Sungguh, hal ini tidak masuk akal, kalau manusia tidak mampu melihat dirinya sebagai mahkluk yang serba cumpen.

Usaha pencarian jawaban teka-teki keabadian mungkin telah dilakukan manusia dengan mengalami konflik batin. Dalam bahasa ketahuidan, hal ini adalah konflik yang terjadi antara kekuatan gelap (non-Tuhan) dan kekuatan terang (Tuhan). Apalagi kalau konteks ketidakpastian, pemahaman terhadap sesuatu teka-teki selalu membawa kesadaran bahwa diri manusia ternyata terbatas. Kematian menjadi dramatis. Apalagi, peristiwa kematian melibatkan seseorang yang dianggap sangat dekat, sangat dicintai, dan sangat dibutuhkan. Akibatnya, meskipun manusia hidup di alam, dia tidak begitu mudah untuk menerima kematian diri sendiri atau kematian orang yang dicintai sebagai kenyataan yang wajar.

Masalah tersebut mengantarkan manusia pada suatu kesadaran bahwa mengapa dia harus mengalami kematian. Akan tetapi, seringkali, manusia masih menjawab persoalan dari segi rasionalitasnya. Pada umumnya, manusia melihat dan memahami kematian melalui pengalaman orang lain. Bahkan, hal itu hanya sekadar melihat kematian yang ditunjukkan dengan terbujurnya jasad karena kehilangan dayanya.

Peristiwa hidup dan mati merupakan fakta esensial dan melibatkan seluruh kedalaman manusia. Seluruh persoalan akan menemukan muaranya ketika manusia mulai merenungkan makna hidup dan makna matinya. Hidup secara konseptual diabstraksikan sebagai suatu hubungan kausalitas dengan kematian. Ajaran yang 
menjelaskan bahwa kesadaran terhadap kematian menjadi peringatan bagi manusia, tentu sangat kontekstual. Hal yang menjadi masalah adalah pandangan yang menganggap hidup sebagai hal kebaikan dan dilawankan kematian. Barangkali, hal ini yang membuat pemahaman manusia atas hidup dan mati hanya sekadar menyentuh matra yang parsial (bdk. Utomo dan Erowati, 2014).

Karena itu, pemahaman terhadap tugas hidup manusia seharusnya lebih ditingkatkan, yaitu bahwa manusia bukanlah sekedar makhluk hidup jasmani yang tidak memiliki amanat hidup yang semestinya. Dengan demikian, masalah yang paling hakiki adalah kualitas hidup dan mati itu sendiri yang akan menentukan martabat manusia secara keseluruhan.

Pemahaman manusia dalam menyingkat tabir kematian diperlukan manusia untuk mengaktualisasikan diri dalam kehidupan ini. Pemahaman atas kematian yang benar menyadarkan manusia bahwa kehidupan dunia bagi manusia hanyalah tahapan yang harus dilalui agar dia kembali ke rahmatullah atau kembali keharibaan Tuhan. Makna hidup yang sesungguhnya adalah bila manusia menemukan makna hidup justru dengan memahami awal dan akhir hidupnya.

\section{SIMPULAN}

Sajak atau puisi yang bermuatan kematian dan ketuhanan karya Abdul Hadi WM dibangun berdasarkan kondisi dan situasi yang melingkupinya. Unsurunsur yang meliputi adalah diksi, rima, persajakan, dan tipografi mampu membangun ketandaan sebagai fungsi dari sajakatau puisi yang berposisi karya sastra. Abdul Hadi WM yang dikategorikan sebagai penyair religius dan menghasilkan karya sastra profetik berbentuk sajak mencerminkan sikap ketuhanan lewat karyanya. Dengan demikian, sajak Abdul Hadi WM menjadi sebagai "sarana dakwah", mengingat dia sebagai penyair. Kematian dan ketuhanan diungkapkan dengan memnafatakan tanda bahasa sehingga makna dan pesan teks dapat tersampaikan oleh pembaca.

\section{DAFTAR PUSTAKA}

Al-Maruf, A.I. (2012). “Dimensi Sufistik dalam Stilistika Puisi ‘Tuhan, Kita Begitu Dekat' Karya Abdul Hadi WM", TSAQAFA, Jurnal Kajian Seni Budaya Islam, 1, (1), Juni 2012, 101-108

Atmosuwito, S. (1989). Perihal Sastra dan Religiusitas dalam Sastra. Bandung: CV Sinar Baru.

Aveling, H. (2003). Rahasia membutuhkan kata: puisi Indonesia 1966-1998. Yogyakarta: Indonesia Tera. 
Damono, S.D. (1983). Kesusasteraan Indonesia Modern: Beberapa Catatan. Jakarta: PT Gramedia

Damono, S.D. (1999). Politik ideologi dan sastra hibrida. Surakarta: Pustaka Firdaus.

Dirjen Dikti. (1981). Metodologi Penelitian IB. Jakarta: Proyek Pengembangan Institusi Pendidikan Tinggi Depdikbud.

Efsa, N.W. (2015). “Manifestasi Ideologi Romantik dalam Puisi-Puisi Acep Zamzam Noor", LITERA, 14, (1) April 2015, 187-204

Hadi W.M., A. (1984a). “Bertemu Saya dan Syeh Siti Jenar”, dalam Dewan Kesenian Jakarta, Dua Puluh Sastrawan Bicara. Jakarta: Penerbit Sinar Harapan.

Hadi W.M., A.. (1984b)."Catatan-catatan Seorang Penyair", dalam Pamusuk Eneste. (Ed). Proses Kreatif: Mengapa dan Bagaimana Saya Mengarang. Jakarta: PT Gramedia.

Herman Ks. (1985). Potret Penyair: Pengembaraan Batin Penyair Indonesia Mutakhir. Jakarta: Yayasan Arus.

Ikranegara. (1978). "Mengenal Puisi-Puisi Sapardi Djoko Damono, Darmanto Jatman, Abdul Hadi W.M.", dalam KOMPAS. 25 Juli.

Junus, U. (1981). Perkembangan Puisi Indonesia dan Melayu Indonesia. Jakarta: Bhratara.

Mardanus, D.. (1978). "Potret Panjang Sebuah Madura Panjang”, dalam SUARA KARYA, 19 November

Rampan, K.L. (1980). Puisi Indonesia Kini: Sebuah Perkenalan. Yogyakarta: CV Nur Cahaya.

Suryadi A.G., L. (1989). Di Balik Sejumlah Nama. Yogyakarta: Gadjah Mada University Press.

Susanto, D. (2015). Kamus Istilah Sastra. Yogyakarta: Pustaka Pelajar

Teeuw, A. (1980). Sastra baru Indonesia, jilid 1. Ende Flores: Nusa Indah.

Teeuw, A. (1984). Sastra dan Ilmu Sastra: Pengantar Teori Sastra. Jakarta: Pustaka Jaya.

Teeuw, A. (1989). Sastra Indonesia Modern II. Jakarta: Pustaka Jaya.

Udin, S. (1985). Memahami Cerpen-Cerpen A.A. Navis. Jakarta: Pusat Pembinaan dan Pengembangan Bahasa.

Utomo, F. dan Erowati, R. (2014). “Dimensi Sufistik dalam Puisi 'Tapi' Karya Sutardji Calzoum Bachri", Jurnal Dialektika, 1, (1), Juni 2014, 1-20 